the death occurred at an earlicr age thin in any case of which I have found a record.

History.-On February 24 of this year there was admitted to the J3abjes' Hospital an infant 3 months of age with an extensive ulceration of the penis. The child was one of seven, four of whom were dead from various acute discases. The parents were healthy as were the other living children. There was no evidence of syphilis or tuberculosis in the family. The infant at birth was a large child, reported to have weighed 11 pounds, and had been breast-fed up to the date of aclmission. When eight days old the operation of ritulal circumeision had been performed, the blood being sucked in the usual mamer. The wound did not heal properly and at the end of $a$ week suppuration was present and ulceration followed which began in the prepuce and gradually extended, up to the time the child was brought to the jospital. A bout two weeks after operation swellings of lympli-nodes in the groin were observed and these also had steadily increased in size although showing no tendency to suppuration. The digestion had been good and the nutrition well preserved until the last three weeks, during which there had been apparently a stendy loss in weight, refusal of food, and slight fever and eough. There was also a discharge from one ear and from the nose. Four or five days previously a scanty maculovesicular eruption had been observed over the trunk and extremities.

Examination.-A well-nourished, normally developed infant was found, weighing $11 \frac{1}{2}$ pounds, who did not appear acutely

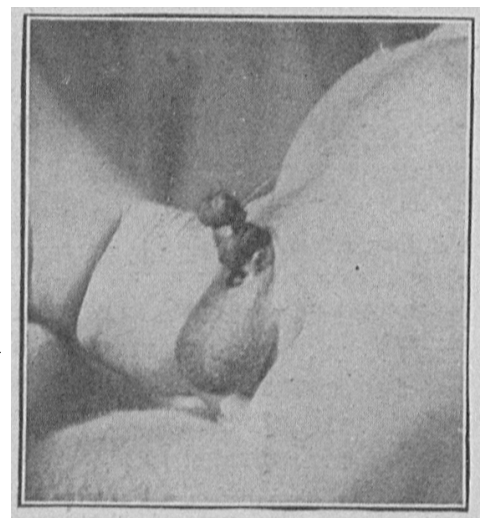

Tubereulous ufceration following circumcision.

ill. Scattered over the body there were fifteen or twenty lesions which closely resembied those of varicella. Two or three were found on the scalp and several over the neck, shoulders, trunk and thighs. None were seen on the hands or feet and none on the mucous membrancs. They were all very similar. in character, from 3 to $4 \mathrm{~mm}$. in diameter, vesicular at the periphery and crusted at the center, giving a somewhat umbilicated appearance. A very narrow zone of redness surrounded the lesions. Apparently there was no itching as they had not been injured by scratching. Elsewhere the skin, including that of palms and soles, was quite normal. Many rnles were present over both lumgs, but there were no signs of consolidation present. The henrt was normal. The abdomen was moderately distended. The spleen was much enlarged, renching fully two inches below the costal margin. The liver also was markedly cnlarged, its lower border being thrse inches below the costal margin. In the inguinal region, both sides, was a chain of large nodular swellings about the size of the last phalanx of the little finger. No signs of suppuration were present. The penis showed eomplete destruction of the skin by ulceration quite to the aldominal wull and to the base of the scrotum (see Fig. 1). It was one granulating surface from which pus was freely discharging. At the meatus was quite a deep ulceration producing an appearance resembling a slight hypospadias. The tuberculin skin test gave a strongly positive reaction. Tubercle bacilli were found in the discharge from the penis, in the sputum and in scrapings from the chtaneons lesions described. The bacilli from the ulcers of the penis were earefully differentiated from smegma bacilli.

Course of Discase.-The child lived sixten days after almis. sion. During this period there was a constant temperature usually varying between 99 and $101 \mathrm{l}$. but ocensionally going to 102 or 103 . There was progressive weakness, steadily increasing eough and rales throughout the chest. The glundular swellings in the groin became larger but did not soften. The other external lympli-nodes were not enlarged. The blood examination at date of admission showed a leukocytosis of $1(6,000$; polymorphonuclears $85 \cdot$ per cent.; lymphorytes 14 per cent.; hemoylobin 65 per cent. Just before death the leukocytes inereased to 24,000 and the polymorphonuclears to 92 per cent. No cerelural symptoms were present, but there was considerable restlessness and lumbar puneture was marle two days before dentl. A clenr fluid under normal pressure was obtained which gave a faint globulin reaction and showed an excess of cells-twenty to the cullic millimeter. The skin lesions present on admission dried up slightly during the period of observation but no new ones appeared. Death occurred from exhaustion.

Nccropsy.-Body well nomrished, the lesions on the skin still showing.

Brain: 'Three or four miliary tubercles were seen over the base and a few over the convexity, but the ventricles were not distended aud no evidenees of meningitis were puesent.

Lungs: The pleura was not adherent; both lungs were everywhere studded with miliny tubereles and small tuberculous nodules. Considerable bronchitis but very little pneumonia was present. The lungs looked much as if they had been infected by a syringeful of tubercle hacilli injected into the trachea. No part of the lungs had escaped. The bronchial and mediastinal lymph-nodes were cascous but not very large, none boing over $1 \frac{1 / 4}{\mathrm{~cm}}$. in diameter, and none showed softening.

Heart: A small yellow tubercle was seen on the coronary artery about its center. A tuberculous nodule, $2 \mathrm{~mm}$. in dinmeter, was found in the wall of the right ventricle, and another smaller one in the wall of the right auricle near the entrance of the superior vena cava. This involved the pericardium, endocardium and cardiac muscle and was cheesy.

Abdomen: The parietal peritoneum was studded with miliary tubercles and tubereulous nodules, especially over the diaphragm. The spleen measured $8 \mathrm{ly} 4.5 \mathrm{~cm}$, and on the surface and in its substance showed many tubereulous nodnles of large and small size. The liver was large, fatty and showed many tubereles on its surface and a few in its substance. The kidneys each contained small caseous tubereulous nodules in moderate numbers, cliefly in the cortex. Both adrenals contained tuberculous nodules, one of which was easeous. 'Two similar ones were found in the pancrens. The stomach and duodenum wore normal, but throughout the rest of the small intestine were grent numbers of tuberculous ulcers some of which extended quite to the peritoneal cont. There were large tuberculous ulcers in the cecum and through. out the colon, even in the rectum.

The mesenteric lympli-nodes were grently enlarged and casseous. The largest inguinal lymph-nodes were $3 \mathrm{~cm}$. in Ingth and $1.5 \mathrm{~cm}$. in breadth. They were caseous but not softened. Fxtending upward from these was a chain of large caseous retroperitoneal lymph-nodes which followed the ilinc arteries and then the aorta. One of the jliac arteries contained a cheesy lymph-node in its adventitia. The tuberculons character of this lesion was confirmed by microscopic exam. ination. Three tubercles were seen on the mucous membrane of the bladder near its base. Both middle ears contained pus.

An opportunity was given to examine the man who had performed the operation. He was a pale, thin, almost emaciated individual, who looked decidedly tuberculons although no physical signs of disease in his lungs could be detected. In his sputum two acid-fast bacilli were found which looked like tubercle bacilli.

This case seems complete and the evidence of infection through the circumcision wound, conclusive. A 
healthy child, born of healthy parents, breast-fed, developed local symptoms of infection within a few days after the operation and these persisterl, being followed after a few wecks by symptoms of general infection which continued until denth. The lesions found at necropsy point strongly to a spreading of the infection through the lympiatic system beginning from the wound, and afterward to a general blood infection. At death, which oceurred when the ehild was $31 / 2$ months old, practically every organ in the body was involved. Specially wortlyy of note in the lesions are the tuberculous nodules of the jliac artery and of the myocardium; the latter lesion I have seen but once before; also the tubereulides of the skin, a lesion which $I$ believe is often overlooked; it las been observerl at the hospital in two other cases during the present season, both patients being young infants.

A search through medical literature brings to light a considerable number of examples of tuberculosis spread by neans of ritual circumcision. In all I lave collected, with the assistance of Doctors $\Lambda$ lan Brown and Staflord McLean, references or jeports more or less detailed of forty other cases. These are of sufficient interest to makc a bricf summary desirable.

\section{SUMMARY OF IITERATURE}

Jandacans's ${ }^{1}$ Caspis: Two cases. The operation was done in the usual manner, the operator sucking the wound one child died and the other recovered after a long illuess. In both enses tuberenlous ulceration oceurred followed by easeons degeneration of the inguinal lymph-notes. Ages of children are not griven; the operator died two months after performing the operation, presumally of tuberoulosis.

LemMans's" Cases: Ten children with almost illentical symptoms infected by the sume operator. 'The operntor subsecpuently died of tuberenlosis. The wound was sucked in the usual manner. The carly signs were similar-irregular, grayish preputial uleers which gradually extended. After two or three weeks there was swellingr of the inguinal lympli-nodes which in most cases suppurated. No microscopic examinations were made, the dingnosis resting on the clinical symptoms.

Ersexmilkg's? Cases: One ense in full. The first dingnosis made was syphilis. Subsequently the patient developed suppuration of the inguinal lymph-nodes and nfterward erysipelas. Tubercle bacilli were found in the sputum of the operator. The author reports that he has seen three similar cases but gives no detuils.

Eve's Casus: Infant 5 months old, admitted with suppurative inguinal adenitis (double) and preputial ulcers. litual circumcision had been done on eighth day. A few weeks afterward inguinal glandular swellings were noticed, which steadily incrensed. Abscesses were opened and curetted. Sinuses followed which were still present at 8 months. At 10 months the child was well. Pus from inguinal lymph-nodes injected into guinea-pigs produced tubereulosis. Operator died from tuberculosis seven and a half months after the cireumcision. Ife did not suck the wound in this ense but merely rijected some wine from his mouth over it. Author refers to another similar ease but gives no details.

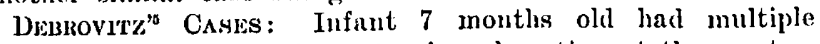
nleers of the prepuce with extensive ulceration at the mentus. linguinal lympli-nodes were much swollen. Subsequently they broke down and were incised. At 12 months of age wounds healed; patient was regarded as well. Operator was examined fund found to be tubereulous; he rinsed his month with red wine before sucking the wound. The writer refers to three other eases, all from the same operntor, but gives no details.

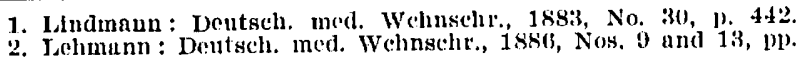
144 ind 218 .

3. Wlsenberg: Rorl. klln. W'chnschr., 1886, No, 35, p. 581

7. Eve: Iancet Lundon, Jan. 28,1888

6. Debrovitz: Pest. med.-chlr. I'lesse, 1S90, No. 23, 1. 520.
Gescheit's" Cases: Five cases with similar clinical symptoms. Details of one case given. l'atient's age 8 months. Cireumeision on the ejghth day. Wound healed in ten days except a dor'sal preputial ulcer. There was edema of the parts. Inguinal lymph-nodes swelled to the size of pigeon's egg. Syphilis was suspected. Antisyphilitic trentment was used without sucecss. All five cases occurred in henlthy families. Three children died within six montlos of meningitis and enteritis; two at 7 and 8 months were living at the time of the report. All showed evidencess of a primary local lesion. The operntor was "thoroughly tubereulous" and had been long ill. Although he had done many previous operations these were the first infants known to have been infected. The anthor does not state how the diagnosis was made in his rases.

Wuly Meren's Case: Infant 12 months old. Fumily healthy. Only ehild. Cireumeised on eighth day by an old man. At 4 weeks inguinal swellings were noticed and syphilis was suspected. Morenrial treatment was begum. At 4 months uleer was noticed on the fremum. Modernte inguinul adenitis was present. Syphilis was still regurded as the dingnosis and trentment continued. There was no improvement under syphilitic trentment. lnguinul lymph-nodes subsecquently broke fown and were enetted. 'Tuberele Incilli in wrent mumbers wore found in the pus. Subsequent history not given.

llormoki's's Casie: Infunt, 8 months old. Family hentlyy. The early symptoms identienl with those in the other anses reported. Syphilis suspected and for a long time antisyphilitic trentment continued without suecess. Jnguinul lymph-nodes subsequently extirpated; found ensenus. Jingnosis estallished by microseopic examination.

Konzw's's Casis: Seven cases of tubereulosis of the penis are reported following circumeision by a rabbi suflering from tuberculosis, Two patients died; two made partial recovery; two were lost sight of, and one recovered. In only one of the families was there tuberculosis. Arluck and Winocouroff state that this report led to a movement of far-reaching socinl effect for the reformation of the performance of ritual circumcision.

Ware's ${ }^{10}$ Cass: Infant, 3 months old. Purents leoulthy. Ritual circumeision done at one week. Two weeks Jater inflammation of the prepuce. Swelling of inguinal lymphnodes, both sides, first seen at 4 weeks. Preputial ulcerntion with modernte secretion also present. Syphilis suspected. Antisyphilitic treatment instituted but withont benefit. Jymph-nodes broke down and were curetted. Tubercle lucilli not found, but the microscopic examination of the lymplsnodes showed giant cells and tuberenlosis was diagnosticated. Case pussed from observation.

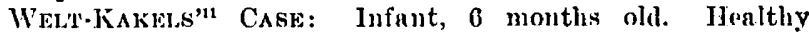
parents. Cireumeision the ninth day by man presumably tuberculous. Wound sucked. Inguinal adenitis observed at the end of four weeks followed by suppuration. Tubercle bacilli found in the pus. Von Pirquet test positive. Lymphnoles removed.

At 4 years of age the child was reported by the writer to be living, but, from physical appearance, was regarded as still suffering from tubereulosis.

J. M. T. FinNey's" CASE: Infant came under observation "some months after the circumcision" with local ulceration and enlargement of inguinal lympls-nodes. Tubercle bacilli in large numbers were obtained from the scrapings. Uleernted areas were curetted. Inguirtal lympli-nodes were excised, both sides. Bucilli were found also in the lymph-nodes. Subsequently tubereulosis of one kne developed. The patient was under olservation many yenrs and is reported never to have had any other evidences of tubereulosis. Investigation by the family revealed the fact that "several other children,"

6. Geschelt: Internnt. klin. Rundschan, 1889, No. 23, p. 904

7. Meyel : New York med. Jrense, June, 1887 .

8. Ilofmokl: Wien. med. l'resse, 1886, Nos. 22 and 23, 11). 714 and 750 .

9. Folizew : Ztschur. d. luss. Gesellseh. d. Volkngsudhtsfilrsorge, 1891; abstr. In Monntsh. 1 . prnkt. Dermat., 1893, xv1, 491 .

10. Ware. M. W.: New York Mrd. Joul., livb. 20, 1898.

11. Welt-isakels, Sura : Al'ch. Hediat., 1909 , p. 400 .

12. Unpublished report. 
sll of whom had been circumcised by the same man, had been similarly infected. He is stated to have been definitely tuber. culous. The parents reported that he spat on a cloth which was used as a dressing for the wound after operation.

Antuck AND Wixocourore's ${ }^{13}$ Cases: Infant of $51 \frac{1}{2}$ montlis. parents healthy. Circumcision on eighth day. Wound was sucked by one of the guests who was tuberculous. Inflammatory signs developed in the course of the next two weeks followed by local ulceration, swelling and breaking down of inguinal lymplenodes. The child wasted with signs of generalized tuberculosis. 'The entire penis ulcerated quite to the scrotum. There was great enlargement of inguinal lymple. nodes. Wassermann was negative; also the von Pirquet test, the latter thonght to be due to the wide-spread infection. One tubercle bacillus was found in scrapings from the preputial uleer. Death occurred four days later. Necropsy showed general tuberculosis involving lungs, intestines, spleen, mesenteric and inguinal lymph-nodes. The infection was believed to be through the lymphatic system.

Of the forty-one patients, including my own, sixteen are known to lave died; seven are reported as having partially recovered or being scrofulous; in twelve the final results were not given; and only six are stated in the histories to have recovered. The youngest filtal case is that of the patient whose history I have reporterl. In several instances death has occurred as late ats 11 months from tubereulous meningitis. The uslal cause of death has been general tuberculosis. In many of the reports several children have been infected by a single operator. 'Thus, in Lelimann's cases, all ten of the children were thus infected; Gescheit reports four infants infected by the same operator; Iindmann, two patients; Debrovitz, four patients. In nearly all of the reports the fact is stated that the families were free from tuberculosis. As a rule the enrliest symptoms of infection have been observed in about a weck after the operation. The wound does not heal, but suppuration occurs and ulceration soon follows. 'The early ulcer may be anywhere on the prepuce but is often on the frenum. It may remain as a localized process or be general. At the end of a second or third week inguinal adenitis develops. In a very considerable number of cases it is reported that the lymph-nodes broke down and abscess formed, usually in two or three months after the initial mfection. The cases in which early suppuration of the inguinal lymph-nodes took place and which were operated on, cither by removal or curctting, were among those in which the results were the best. The symptoms of a wide-spread general infection rarely oceurred earlier than the thisd or fourth month.

The diagnosis bas been made in many of the cases by the clinical symptoms and history alone. Some of these were reported before systematic search for the tubercle bacillus in wounds was practiced or modern tuberenlin tests were employed. In nearly all of the jater cases reported, the diagnosis las been established by the discovery of the bacilli in the inguinal abscesses, sometimes from the preputial uleers. In the latter situation they must be carefully differentiated from smerma bacilli. 'That the infection spreads through the lymphatic system seems certain and carly removal of the inguinal lymph-nodes would therefore appear to be the most important measure to be employed in checking the extension of the infection. To be suecessful this must of course be done early.

In a very large proportion of the cases reported the first diagnosis made was syphilis, and the patients were treated for weeks and montlis by antisyphilitic mens-

1:3. Arluek Hnd Winocouroff: Boitr. \&. Tuber's., 1912, xxil, 341. ures without benefit and with loss of valuable time. It is my own belief that syphilis is less frequently acquired in this manner than is tuberculosis and that the latter disease should be first suspected. With the modern means of diagnosis in tuberculosis the enrly recognition of these cases ouglit not to be diffieult. While the number of reported instances of tuberculosis acquired through circuncision is considerable there must be a very much larger number that have never found their way into literature. It is certain also that syphilis has been spread in this manner. These facts lead me to emphasize the statement made by the late Professor Maas, the German surgeon, that "it is the duty of the physician to raise his protest against the performance of ritualistic circumcision in every casc."

11 West Fifty-Fifth Street.

\section{PEMPIIIGUS · FOIJACEUS *}

\section{J. B. KESSIER, M.D. IOW'A CITY, JOWA}

Pemphigus foliaceus was first described by Cazenare in 1844 . It is a rare skin disease oceurring about once in five thousund casses. Radcliff. Crocker, with his almost unlimited experience up to the year 1903, encountered it only six times-in five women and one man. It is one of the rure forms of dermatitis that has a universal distribution, with the formation of flaced bullae which quickly rupture and discharge their contents, leaving an inflamed, excoriated and fissured surface.

The disease may begin as a pempligus foliaceus or from a chronic pempligus vulgaris, the bullae changing their character. It may develop from a dermatitis herpetiformis, according to Hallopeau, or from a general dermatitis exfoliativa.

The bullae are flaceid and at times do not raise the epidermis perceptibly; if the amount of fluid is greater, it extencls the fower part of the bullae. The contents are purulent, almost from the beginning. 'The mucous membranes may be involved. 'There is a feeling of' stiffness and tension in the skin where the eprdermis has dried. 'There is not much itching or burning as a l'ule, but at times it is severe and paroxysmal, owing to the exposure of the corium to the air.

After the clisease has lasted for a time, there may be fever, either intermittent or continuous, or the temperature may remain norma!.

The etiology of this disease is still in doubt; chills may be a causative factor, or violent emotions, according to Hallopeau.

In making a diagnosis we must differentiate from universal ecicna, pityriasis rubra, lichen acuminatus universalis, ecema rubrum and pempligus vegetans.

'The disease may be years in duration, but, sooner or later, the patient succumbs.

I'wo cases which have conc under my observation since March 5, 1912, may be of interest to the general practitioner, il not to the dermatologist.

Case 1.-Mrs. M., aged 5 (i, a native of Denmark, who had come to Amerien the previous October to visit a muried daughter living in nortlor'n lowil, was armitted to the University llospital. Nareh 5. 1912. Her father died at the age of 61 ; mother alied anged 36 or 38 ; one brother and one sister are living and well; three brothers are dend, canse unksown.

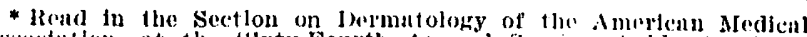

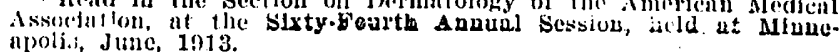

